\title{
Evaluasi Nilai Ekspor dan Impor Regional Association of Southeast Asian Nations Sebelum dan Setelah Krisis Ekonomi Tahun 1998
}

\author{
Agus Eko Sujianto, Sokib \\ Institut Agama Islam Negeri Tulungagung \\ agusekosujianto@gmail.com
}

\begin{abstract}
The purposes of this research are to evaluate the difference of export value of ASEAN member countries before and after economic crisis in 1998 and to evaluate the difference of import value of ASEAN member countries before and after economic crisis in 1998. While export and import become the main variable of research this sekgus is an important component of the preparation of the trade balance. The research data used secondary data of export and import in 1982-1997 (period before economic crisis in 1998) and 1999-2014 (period after economic crisis in 1998) from annual publication of ADB. Based on the Paired Sample t-Test test it can be argued that: the export value of ASEAN member countries before and after the crisis differed significantly and the import value of ASEAN member countries before and after crisis differed significantly
\end{abstract}

Keywords: Surplus, Deficit, Export, Import

\begin{abstract}
Abstrak
Tujuan penelitian ini yaitu mengevaluasi perbedaan nilai ekspor negaranegara anggota ASEAN sebelum dan setelah krisis moneter 1998 serta mengevaluasi perbedaan nilai impor negara-negara anggota ASEAN sebelum dan setelah krisis moneter 1998. Sedangkan ekspor dan impor yang menjadi variabel utama penelitian ini sekalgus merupakan komponen penting penyusunan neraca perdagangan. Data penelitian menggunakan data sekunder yaitu ekspor dan impor tabun 1982-1997 (periode sebelum krisis moneter 1998) dan tabun 1999-2014 (periode setelah krisis moneter 1998) dari publikasi ADB yang bersifat annual. Berdasar uji Paired Sample t-Test dapat dikemukakan bahwa: nilai ekspor negara-negara anggota ASEAN sebelum dan setelah krisis berbeda secara signifikan dan nilai impor negaranegara anggota ASEAN sebelum dan setelah krisis berbeda secara signifikan.
\end{abstract}

Kata Kunci: Surplus, Defisit, Ekspor, Impor

Permalink/DOI:http://dx.doi.org/10.18326/infsl3.v11i2.329-350 


\section{Pendahuluan}

Krisis ekonomi (Krismon) di Association of Southeast Asian Nations (ASEAN) yang diawali dengan terjadinya krisis keuangan Asia pada tahun 1997, dimana pada waktu itu salah satu negara di ASEAN yaitu Thailand terbebani dengan hutang luar negeri yang sangat besar sehingga memutuskan mengambangkan mata uang baht. Dampak selanjutnya dialami oleh kebanyakan negara di kawasan ini seperti Korea Selatan, Hongkong, Malaysia, Filipina dan tentunya Indonesia.

Uniknya, Krismon yang dialami oleh Indonesia berimplikasi pada peristiwa politik, dimana Salamah (2001: 65-76) mengemukakan: (1) ekonom klasik seperti Krugman melihat krisis ekonomi yang melanda Asia khususnya Indonesia disebabkan karena faktor domestik, antara lain praktik crony capitalism dan lemahnya struktur finansial yang berkaitan dengan kebijakan ekonomi makro; (2) ekonom Keynesian seperti Kindlebeger melihat krisis itu terjadi karena sentimen pasar finansial yang menyebabkan kepanikan dan menimbulkan proses penularan pada sistem ekonomi nasional; (3) Djiwandono melihat bahwa krisis yang melanda Asia khususnya Indonesia karena kombinasi kekuatan dari luar serta lemahnya struktur finansial dan ekonomi domestik.

Implikasi berikutnya, Krismon sebagaimana dikemukakan oleh Salamah di atas berdampak buruk terhadap perekonomian nasional yaitu dengan dilikuidasinya 16 bank swasta nasional pada 1 Nopember 1997 yang berimplikasi terhadap penurunan pertumbuhan ekonomi, inflasi meningkat, pengangguran cenderung meningkat, nilai ekspor dan impor turun. Disamping itu kondisi makro ekonomi Indonesia terjadi fluktuasi dan cenderung menurun kinerjanya khususnya pada periode jangka pendek sebelum dan setelah Krismon tahun 1998.

Lantas bagaimana kondisi perekonomian negara-negara regional di kawasan ASEAN? Apakah terdapat perbedaan yang signifikan secara statistik khususnya terhadap neraca perdagangan regional (ekspor dan impor) di kawasan ASEAN? 
Kegiatan perdagangan regional di kawasan ASEAN ini sangat penting dilakukan, sebagaimana dikemukakan oleh Sukirno (1998: 396), ahli-ahli ekonomi klasik berpandangan bahwa perdagangan luar negeri mempunyai potensi untuk memberikan tiga sumbangan penting dalam pembangunan ekonomi yaitu: (1) mempertinggi efisiensi penggunaan faktorfaktor produksi. Pandangan ini bersumber dari keyakinan kaum klasik mengenai manfaat yang dapat diperoleh dari melakukan spesialisasi; (2) memperluas pasar produksi dalam negeri. Dalam setiap perekonomian selalu timbul keadaan dimana beberapa perusahaan atau industri mempunyai kapasitas produksi yang tidak sepenuhnya digunakan serta (3) mempertinggi produktivitas kegiatan ekonomi. Dengan melakukan perdagangan luar negeri sesuatu negara akan menjalin perhubungan yang erat dengan negara-negara lain. Ini memungkinkan negara tersebut untuk: (1) mempelajari teknik produksi yang lebih baik; (2) mengimpor barang-barang modal baru yang lebih tinggi produktivitasnya; (3) mempelajari pandangan-pandangan baru yang akan memperbaiki cara kerja dan cara memimpin perusahaan yang sedang dijalankan.

\section{Tinjauan Pustaka}

Ekonomi merupakan salah satu cabang dari ilmu sosial yang mempelajari perilaku pelaku ekonomi dalam memenuhi kebutuhannya dengan keterbatasan sumberdaya yang tersedia. Mengingat manusia merupakan makhluk sosial dan ekonomi merupakan cabang dari ilmu sosial, maka terdapat ketergantungan manusia yang satu dengan yang lainnya untuk memenuhi kebutuhannya.

Manusia tidak dapat hidup sendirian, karena membutuhkan interaksi dengan manusia yang lainnya untuk memenuhi kebutuhan-kebutuhan ekonominya yang mustahil dapat dipenuhi secara individual. Misalnya seorang petani, yang memiliki lahan atau sawah. Mereka membutuhkan tenagakerja, benih, obatobatan, dan lain sebagainya yang mustahil dapat mereka penuhi sendiri, dengan demikian membutuhkan orang lain yang dapat mengerjakan sawah, menyediakan benih dan memproduksi obatobatan. 
Sementara Sukirno (1996: 4) menjelaskan, dalam kehidupan sehari-hari individu-individu, perusahaan-perusahaan dan masyarakat secara keseluruhannya akan selalu menghadapi persoalan-persoalan yang bersifat ekonomi, yaitu persoalan yang menghendaki seseorang, sesuatu perusahaan atau suatu masyarakat membuat keputusan tentang cara yang terbaik untuk melakukan sesuatu kegiatan ekonomi.

Individu-individu, perusahaan-perusahaan dan masyarakat ini disebut pelaku ekonomi, dimana keputusan yang diambil dalam rangka untuk memenuhi kebutuhan hidupnya sehingga diperlukan skala prioritas untuk membuat pilihan. Keputusan dalam membuat pilihan ini didasarkan pada ketersediaan sumber daya atau faktor produksi yang bersifat terbatas.

Hal ini relevan dengan penjelasan Sukirno bahwa masalah ekonomi pokok yang dihadapi setiap masyarakat yaitu masalah kelangkaan atau kekurangan. Kelangkaan atau kekurangan tersebut berlaku sebagai akibat dari ketidakseimbangan diantara kebutuhan masyarakat dengan faktor-faktor produksi yang tersedia dalam masyarakat. Di satu pihak, dalam setiap masyarakat selalu akan terdapat keinginan yang relatif tidak terbatas untuk menikmati berbagai jenis barang yang dapat memenuhi kebutuhan masyarakat. Sebaliknya, di lain pihak, sumber-sumber daya atau faktor-faktor produksi yang dapat digunakan untuk memproduksikan barangbarang tersebut adalah relatif terbatas.

Kemudian ekonomi dibagi menjadi dua yaitu ekonomi mikro dan ekonomi makro sebagaimana dikemukakan Sukirno (1996:34) bahwa teori-teori dasar dalam ilmu ekonomi dibedakan menjadi dua kumpulan teori, yaitu teori mikro ekonomi dan makro ekonomi. Mikro ekonomi pada umumnya meliputi bagian-bagian kecil dari keseluruhan kegiatan perekonomian dan lebih menitikberatkan kepada analisis mengenai masalah membuat pilihan untuk: (1) mewujudkan efisiensi dalam penggunaan sumber-sumber dan (2) mencapai kepuasan yang maksimum. Sedangkan analisis-analisis dalam teori makro ekonomi lebih global atau lebih menyeluruh sifatnya. Analisis-analisis dalam makro ekonomi menerangkan tentang: (1) pentingnya segi permintaan dalam menentukan tingkat 
kegiatan dalam perekonomian dan (2) pentingnya kebijakan dan campurtangan pemerintah untuk mewujudkan prestasi kegiatan ekonomi di tingkat yang dikehendaki.

Jika masalah dalam perekonomian yaitu keterbatasan atau kelangkaan sebagaimana dikemukakan oleh Sloman dan Norris di atas, dan jika ekonomi dibagi menjadi ekonomi mikro dan makro, maka masalah ekonomi mikro dan masalah ekonomi makro tentu berbeda. Namun demikian walaupun terdapat perbedaan tentang teori-teori dasar dalam ilmu ekonomi, juga terdapat persamaan yang berangkat dari keterbatasan atau kelangkaan sumberdaya. Kelangkaan ini mengakibatkan munculnya skala prioritas untuk meminimalisir permasalahan ekonomi manusia baik dalam skala mikro ekonomi maupun makro ekonomi.

Masalah mikro ekonomi terkait tiga pertanyaan yaitu: (1) apakah jenis-jenis barang dan jasa yang harus diproduksikan?; (2) bagaimanakah caranya memproduksi berbagai barang dan jasa yang dibutuhkan tersebut? dan (3) untuk siapakah berbagai barang dan jasa tersebut diproduksikan? (Sukirno, 1996: 4-5). Masalah makro ekonomi utama yang selalu dihadapi sesuatu negara yaitu: masalah pertumbuhan ekonomi, masalah ketidakstabilan kegiatan ekonomi, masalah pengangguran dan inflasi serta masalah neraca perdagangan dan neraca pembayaran (Sukirno, 1996: 9-10).

Sedangkan neraca perdagangan adalah perbedaan antara nilai ekspor dan impor suatu negara pada periode tertentu biasanya satu tahun yang diukur menggunakan mata uang yang berlaku. Neraca positif artinya terjadi surplus neraca perdagangan yaitu ketika nilai ekspor lebih tinggi dibandingkan nilai impor, dan sebaliknya nilai ekspor lebih rendah dibandingkan nilai impor untuk neraca negatif disebut defisit. Neraca pedagangan seringkali disebut sebagai neraca perdagangan atau neraca perdagangan internasional.

O'Sullivan dan Sheffrin (2003: 462), mendefinisikan bahwa neraca perdagangan, neraca komersial, atau ekspor neto adalah perbedaan antara nilai moneter ekspor dan impor suatu negara selama periode tertentu. Perbedaan ini mengandung pengertian selisih, sehingga ketika selisih ekspor dan impor ini 
positif maka neraca perdagangannya surplus. Dan jika selisihnya negatif maka terjadi yang namanya defisit neraca perdagangan. Dengan demikian neraca perdagangan merupakan suatu catatan tentang nilai barang-barang yang diekspor maupun diimpor oleh suatu negara yang dapat digunakan untuk mengukur kondisi dan perkembangan perdagangan internasional suatu bangsa. Neraca perdagangan juga menunjukkan perkembangan besarnya utang bagi negara pengimpor (importir) dan piutang bagi negara pengekspor (eksportir).

Menurut Samuelson dan Nordhaus (2001: 325) ekspor adalah barang dan jasa yang diproduksi di dalam negeri dan dibeli oleh orang-orang asing. Menurut Mankiw (2006: 424), ekspor juga berarti barang-barang yang diproduksi di dalam negeri dan dijual di luar negeri. Sedangkan menurut Setyowati, et al (2004: 93), ekspor suatu negara biasanya terdiri dari barang dan jasa yang dihasilkan di dalam negeri sendiri. Namun demikian tidak menutup kemungkinan mengekspor barang-barang yang diimpor, atau beberapa barang diimpor dan sebagian di ekspor kembali.

Berdasar pemikiran Samuelson dan Nordhaus serta Mankiw tersebut dapat dikemukakan bahwa ekspor merupakan suatu aktivitas ekonomi terkait barang dan jasa yang diproduksi oleh suatu perekonomian di dalam negeri dan dipasarkan untuk memenuhi kebutuhan perekonomian di luar negeri, sehingga diperoleh devisa untuk melakukan pembangunan pada negara yang melakukan ekspor tersebut. Sedangkan berdasar pemikiran Setyowati, et al, secara eksplisit dikemukakan bahwa ekspor tidak saja terkait barang dan jasa jadi yang dihasilkan suatu negara, tetapi juga barang yang diimpor yang selanjutnya di ekspor kembali. Dalam kaitannya dengan devisa sebagai implikasi dari kegiatan perdangan luar negeri dapat dijelaskan bahwa, devisa merupakan semua benda yang bisa digunakan untuk transaksi pembayaran perdagangan luar negeri menurut standar dunia internasional. Salah satu jenis dari devisa yaitu valuta asing (valas). Valas yaitu mata uang yang dapat diterima oleh hampir semua negara di dunia seperti Dollar Amerika Serikat, Yen Jepang, Euro, Poundsterling Inggris dan sebagainya. 
Kegiatan perdagangan luar negeri dalam bentuk ekspor inilah yang selanjutnya menghasilkan valuta asing sebagaimana dikemukakan Samuelson dan Nordhaus (2001: 302) yang mengemukakan bahwa ekspor menghasilkan valuta asing, sehingga merupakan kredit. Menurut Setyowati, et al (2004: 95), kebanyakan model-model aliran Keynes mengenai perekonomian terbuka mengasumsikan bahwa ekspor tidak tergantung pada tingkat pendapatan. Dengan kata lain ekspor merupakan variabel eksogen yang nilainya tidak dipengaruhi pendapatan nasional negara tersebut.

Impor merupakan barang-barang yang diproduksi di luar negeri dan dijual di dalam negeri (Mankiw, 2006: 424). Dengan kata lain bahwa kegiatan impor ini merupakan kegiatan ekonomi yang dilaksanakan baik di luar negeri maupun dalam negeri. Produsen produk impor yaitu pelaku ekonomi di luar negeri sedangkan konsumen impor yaitu pelaku ekonomi di dalam negeri, sehingga bagi produsen memerlukan produk kompetitif dan bagi konsumen memerlukan sejumlah uang untuk mendatangkan barang-barang impor ini. Uang dalam kontek makro ekonomi disebut pendapatan nasional.

Setyowati, et al (2004: 95) mengemukakan bahwa impor suatu negara berhubungan secara positif dengan tingkat pendapatan. Hubungan positif ini mempunyai dua penjelasan. Pertama, bahwa impor sering kali digunakan sebagai masukan untuk menghasilkan barang-barang dan jasa-jasa yang merupakan produk nasional negara tersebut. Kedua, bahwa impor mengikuti permintaan secara keseluruhan atau "penyerapan" dalam perekonomian. Semakin banyak kita berbelanja barang-barang dan jasa, ada kemungkinan dipenuhi dari luar negeri juga, sehingga semakin banyak pula kita berbelanja barang-barang dan jasa dari luar negeri yang merupakan impor.

Berdasar pemikiran di atas bahwa impor tidak saja terkait dengan barang tetapi juga jasa dari luar negeri. Barang merupakan setiap benda baik berwujud maupun tidak berwujud, baik bergerak maupun tidak bergerak, dapat dihabiskan maupun tidak dapat dihabiskan, yang dapat untuk diperjual-belikan atau 
diperdagangkan, dipakai, dipergunakan, atau dimanfaatkan oleh konsumen. Jasa merupakan setiap layanan yang berbentuk pekerjaan atau prestasi yang disediakan bagi masyarakat untuk dimanfaatkan oleh konsumen.

Dengan demikian maka yang dimaksud dengan impor barang adalah kegiatan memasukkan barang ke dalam negeri. Impor jasa adalah kegiatan penyediaan jasa asing untuk digunakan di dalam wilayah Republik Indonesia. Contoh impor jasa yaitu: jasa insinyur atau ahli suatu bidang (misalnya perminyakan), jasa modal, jasa transportasi, jasa tenaga ahli, jasa pendidikan, jasa mengekspor kendaraan bermotor, alat kebutuhan rumah tangga, alat elektronika dan lain sebagainya.

Besarnya impor suatu negara ditentukan oleh sampai dimana kesanggupan barang-barang yang diproduksikan di negara-negara lain untuk bersaing dengan barang-barang yang dihasilkan di negara itu. Apabila barang-barang dari luar negeri mutunya lebih baik, atau harga-harganya lebih murah daripada barang-barang yang sama yang dihasilkan di dalam negari, maka akan terdapat kecenderungan bahwa negara tersebut akan mengimpor lebih banyak barang dari luar negeri. Akan tetapi apakah kecenderungan tersebut akan terwujud atau tidak, masih tergantung pada kesanggupan penduduk negara itu membayar impor tersebut. Ini berarti bahwa impor dipengaruhi oleh besarnya pendapatan nasional daripada oleh kemampuan barang-barang luar negeri untuk bersaing dengan barang-barang produksi dalam negeri. Sukirno (1998: 383-384), menjelaskan bahwa semakin besar pendapatan nasional, maka semakin besar pula nilai impor.

Perdagangan internasional dalam bentuk ekspor dan impor ini merupakan sarana untuk melakukan pertukaran barang dan jasa internasional. Dalam lima puluh tahun terakhir, perdagangan internasional telah tumbuh dan berkembang secara drastis dan dalam ukuran yang besar. Hal ini disebabkan oleh adanya kerjasama yang dilakukan oleh berbagai negara untuk menghilangkan proteksi perdagangan dan adanya keinginan untuk mempromosikan perdagangan barang dan jasa secara bebas (Huda, et al, 2008: 100). 
Menurut Benny (2013: 1406-1415), perdagangan internasional membutuhkan devisa sebagaimana dikemukakan oleh Benny, bahwa era global saat ini mendorong negara-negara ke dunia perdagangan internasional. Salah satu alat dan sumber pembiayaan yang sangat penting dalam perdagangan internasional adalah cadangan devisa. Cadangan devisa merupakan posisi bersih aktiva luar negeri pemerintah dan bank-bank devisa yang diperlukan untuk membiayai impor. Ekspor berpengaruh positif dan signifikan terhadap cadangan devisa, sementara impor berpengaruh negatif dan signifikan terhadap cadangan devisa. Artinya, jika ekspor naik maka posisi cadangan devisa akan naik dan jika impor naik maka posisi cadangan devisa akan turun.

Berdasar pemikiran singkat di atas dapat dikemukakan bahwa perdagangan internasional terdiri dari ekspor dan impor. Ekspor merupakan kegiatan ekonomi untuk menjual produk dalam negeri ke negara-negara mitra di luar negeri. Sedangkan impor merupakan kegiatan ekonomi untuk membeli produk-produk dari negara mitra di luar negeri. Ekspor akan mendatangkan devisa ke dalam negeri, sedangkan impor suatu negara akan mengeluarkan devisa untuk mendatangkan produk dari luar negeri.

Bentuk perdagangan internasional yaitu ekspor dan impor yang merupakan kegiatan jual beli lintas negara. Septididya (2013: 1) mengemukakan, dalam transaksi perdagangan yang berskala internasional yang lebih dikenal dengan istilah ekspor impor, pada hakikatnya adalah suatu transaksi yang sederhana dan tidak lebih dari membeli dan menjual barang antara pengusahapengusaha yang bertempat di negara-negara yang berbeda. Dalam praktiknya tidak jarang timbul masalah yang kompleks antara pengusaha-pengusaha, dikarenakan terpisah oleh batas kenegaraan (geopolitik), struktur geografi, sosial dan demografi, yang menyebabkan adanya karakteristik bentuk transaksi, baik bentuk perjanjian maupun bentuk pembayarannya. Kegiatan perdagangan internasional yang meliputi transaksi ekspor dan impor dapat dilaksanakan dengan baik, apabila hubungan pembayarannya dapat diselenggarakan dengan lancar dan terjamin bagi semua pihak. 
Sedangkan konsep dasar yang digunakan sebagai rujukan perdagangan internasional menurut Islam sebagaimana dijelaskan oleh Mannan (1997: 296-297) bahwa Islam menganjurkan semua kegiatan yang halal dan konsisten dengan jiwa Islam serta yang dikehendaki oleh perekonomian Islam yaitu pencapaian keuntungan sosial yang sebanyak-banyaknya. Pada dasarnya Islam menerima perdagangan bebas. Berdasar pemikiran Mannan tersebut, perdagangan bebas merupakan suatu keniscayaan mengingat manusia sebagai makhluk sosial yang selalu berinteraksi dengan orang lain dan negara-negara lainnya. Bahkan perdagangan antar negara ini juga telah dicontohkan dan dilakukan pada zaman Khalifah Umar Radhiyallabu Anhu, baik di bidang ekonomi maupun non ekonomi.

Al-Haritsi (2006: 565) menjelaskan bahwa, melakukan akad kesepakatan dagang antar negara merupakan hal yang tidak dapat dihindari untuk memotivasi dan pengaturan hubungan dagang agar dapat merealisasikan kemaslahatan pihak-pihak yang melakukan kesepakatan. Bahkan perjanjian dagang pemerintah Islam dengan non muslim seyogianya memenuhi dasar-dasar sebagai berikut: (1) harus terdapat kemaslahatan yang kuat bagi kaum muslimin dan poin-poinnya tidak boleh mencakup hal yang diharamkan menurut syariah; (2) harus memperhatikan sisi keamanan kaum muslimin serta (3) menepati poin-poin perjanjian ekonomi.

Mengingat perdagangan internasional merupakan kegiatan ekonomi dimana suatu negara menjual dan membeli suatu produk dari dan ke suatu negara, maka Suwignyo (2010: 125) mendeskripsikan bahwa jual beli atau perdagangan menurut bahasa berarti al-bai, at-tijarah dan al-mubadalah. Inti jual beli secara istilah ialah perjanjian antardua pihak atau lebih dalam transaksi pemindahan kepemilikan atas suatu barang yang mempunyai nilai dan dapat terukur dengan satuan moneter. Ukuran nilai tersebut menjadi dasar atas penentuan harga barang dan kebijakan pengambilan keuntungan. Karenanya perlu tawar menawar sebagai bentuk pemenuhan hak pilih saat transaksi terjadi. 
Penelitian terdahulu yang relevan dengan penelitian ini sebagaimana dilaksanakan oleh Nugrahani dan Tarioko (2011) yang bertujuan menguji pertumbuhan ekonomi, investasi domestik dan ekspor pada kondisi sebelum dan sesudah krisis. Hasil penelitian menunjukkan investasi domestik dan ekspor antara kondisi sebelum dan sesudah berbeda, sedangkan pada pertumbuhan ekonomi tidak berbeda baik pada kondisi kondisi sebelum maupun sesudah krisis.

Ragimun (2016) dalam penelitiannya yang bertujuan untuk menganalisis kinerja ekonomi perdagangan Indonesia dengan China terutama dilihat dari investasi China ke Indonesia sebelum dan sesudah ACFTA termasuk tantangan serta strategi menangkap peluang investasi China ke Indonesia. Hasil penelitian menunjukkan bahwa: (1) pertumbuhan perdagangan China Indonesia mengalami peningkatan pasca ACFTA. Rata-rata share total perdagangan Indonesia-Cina terhadap Total Perdagangan Semua Negara dengan Indonesia sebelum ACFTA 6,87\%, meningkat menjadi 9,40\% pasca ACFTA; (2) rata-rata ekspor sesudah ACFTA juga mengalami kenaikan dibanding sebelumnya. Pasca ACFTA rata-rata ekspor per tahun hanya mencapai US\$3.770, kemudian naik menjadi US\$7.940 per tahun pasca ACFTA; (3) namun hal ini tidak diikuti perkembangan investasi China ke Indonesia yang masih relatif kecil. Investasi China ke Indonesia dibandingkan dengan total investasi dunia ke Indonesia sesudah perjanjian AC FTA tidak mengalami peningkatan rata-rata hanya sebesar $0,006 \%$, sebelumnya juga rata-rata sebesar $0,006 \%$.

Studi Safitriani (2014) yang bertujuan mengkaji pengaruh arus perdagangan internasional dan Foreign Direct Invesment (FDI) di Indonesia dengan menggunakan analisis regresi secara terpisah. Hasil penelitian ini menunjukkan terdapat hubungan satu arah antara ekspor dan FDI dan terdapat hubungan dua arah antara impor dan FDI di Indonesia. Temuan ini mengindikasikan bahwa FDI memberikan dampak jangka panjang yang positif terhadap ekspor, sementara dalam jangka pendek, FDI berdampak negatif terhadap ekspor. Namun dalam hal impor, ditemukan bahwa FDI memiliki dampak positif terhadap impor meskipun secara statistik 
tidak signifikan. Oleh karena itu pemerintah perlu mengambil langkah untuk meningkatkan FDI di Indonesia, tidak hanya pada sektor domestik tetapi juga pada sektor yang berorientasi ekspor.

Kajian empiris Sabaruddin (2005) yang mengevaluasi dampak perdagangan internasional Indonesia terhadap kesejahteraan masyarakat, dengan memanfaatkan dua perangkat analisa yaitu Sistem Neraca Sosial Ekonomi 2008 (SNSE 2008) dan Structural Path Analysis (SPA). Pada sisi ekspor, hasil simulasi menunjukkan bahwa untuk kelompok komoditi Pertanian, ekspor ke luar negeri mempengaruhi kesejahteraan masyarakat lebih melalui jalur tenaga kerja. Pada kelompok industri, jalur modal lebih dominan yang ditunjukkan dengan besaran pengganda yang lebih besar relatif terhadap jalur tenaga kerja. Dari sisi impor, dampak terhadap tingkat kesejahteraan masyarakat disalurkan melalui dua jalur utama yakni jalur produksi dan jalur penerimaan pajak. Faktor produksi yang terlibat dalam proses ini terdiri dari pekerja dengan pendapatan menengah yang tinggal di perkotaan dan pengusaha berpendapatan menengah baik di pedesaan maupun di perkotaan.

Menurut Wahyuni dan Indarwati (2010), ekspor dan impor adalah kunci penting bagi devisa suatu bangsa. Tujuan dari penelitian ini adalah untuk menganalisis pengaruh tingkat pertumbuhan ekspor impor China dan ekspor dan impor Indonesia menuju diterapkannya ACFTA. Data kuartalan selama 2007,1-2009,4 digunakan untuk analisis. Dengan menggunakan regresi menganalisis, hasilnya menunjukkan bahwa impor meningkat China dan GDP China akan meningkatkan ekspor Indonesia tingkat tumbuh. Dan impor Indonesia juga dipengaruhi oleh ekspor China karena tingginya kebutuhan Indonesia pada produk impor expecially produk China. Berdasarkan situasi di atas, penelitian ini menunjukkan bahwa pelaksanaan ACFTA sejak Januari 2010, pemerintah Indonesia yang memerlukan dukungan industrialis lokal untuk mengembangkan produk mereka agar produk dapat bersaing dengan produk Cina pada perdagangan bebas internasional dan domestik. 
Studi Maramis (2013: 1431-1443) yang menguji hipotesis yaitu: (1) pertumbuhan ekonomi, konsumsi, investasi dan ekspor neto Indonesia diduga terdapat perbedaan pada kondisi antara sebelum dan sesudah krisis financial global 2008; (2) pertumbuhan ekonomi, konsumsi, investasi dan ekspor neto Sulawesi Utara diduga terdapat perbedaan pada kondisi antara sebelum dan sesudah krisis financial global 2008 dan (3) situasi perekonomian di Sulawesi utara berdasarkan variabel-variabel tersebut diduga lebih baik dari pada kondisi perekonomian Indonesia dengan variabel-variabel yang sama antara sebelum dan sesudah krisis financial global 2008. Hasil penelitian: (1) terdapat perbedaan kondisi pertumbuhan ekonomi, konsumsi, investasi dan ekspor neto Sulawesi Utara yang signifikan antara sebelum dan sesudah krisis finansial global 2008; (2) terdapat perbedaan kondisi pertumbuhan ekonomi, konsumsi, investasi dan ekspor neto Indonesia yang signifikan antara sebelum dan sesudah krisis finansial global 2008 serta (3) kenaikan kondisi pertumbuhan ekonomi, konsumsi dan investasi Sulawesi Utara lebih signifikan dibandingkan dengan Indonesia. Hal menggambarkan Kondisi Perekonomian Sulawesi Utara lebih mengalami peningkatan setelah terjadi krisis finansial global 2008 dibandingkan dengan Indonesia.

Gultom, et al (2013) dalam penelitiannya yang bertujuan untuk menganalisis neraca perdagangan jeruk, volume impor jeruk, harga jeruk impor, volume ekspor jeruk, harga jeruk ekspor, harga jeruk domestik Sumatera Utara sebelum dan sesudah CAFTA (China ASEAN Free Trade Area). Hasil penelitian menunjukkan neraca perdagangan jeruk Sumatera Utara sebelum dan sesudah CAFTA mengalami defisit. Nilai impor lebih tinggi dibandingkan dengan nilai ekspor. Terdapat perbedaan nyata antara volume impor jeruk, harga jeruk impor, volume ekspor jeruk, harga jeruk domestik sebelum dan sesudah CAFTA (China ASEAN Free Trade Area). Tidak terdapat perbedaan nyata harga jeruk ekspor sebelum dan sesudah CAFTA (China ASEAN Free Trade Area). Volume impor jeruk sesudah CAFTA lebih tinggi dibandingkan sebelum CAFTA. Volume ekspor jeruk sesudah CAFTA lebih rendah dibandingkan dengan sebelum CAFTA. Harga jeruk impor, harga jeruk ekspor, 
harga jeruk domestik Sumatera Utara lebih mahal sesudah CAFTA dibandingkan dengan sesudah CAFTA.

Penelitian Kartika (2008) menyebutkan bahwa pasca krisis finansial 2008, pemerintah Amerika Serikat berupaya melakukan upaya penyelamatan sektor ekonomi domestik pada masa resesi ekonomi. Dalam sektor finansial, pemerintah Amerika Serikat meratifikasi berbagai kebijakan yang memungkinkan adanya bantuan finansial terhadap bank maupun lembaga keuangan yang terkena dampak krisis. Dari sektor industri dan perdagangan, presiden Amerika Serikat Barrack Obama menyerukan slogan "buy American" pada bulan Februari 2009 mendorong masyarakat Amerika Serikat untuk membeli produk domestik serta penggunaan bahan baku lokal dalam setiap pembelanjaan proyek pemerintah. Selain itu pemerintah Amerika Serikat juga memberlakukan restriksi terhadap berbagai produk impor dari berbagai negara, baik dengan hambatan tarif maupun non tarif serta bersifat teknis maupun non teknis. Berbagai kebijakan yang dikeluarkan oleh pemerintah Amerika Serikat tersebut dinilai bersifat proteksionis dan tidak konsisten dengan prinsip WTO yang mengedepankan tiga hal yaitu anti diskriminasi produk, mengurangi atau menghilangkan batasan dan hambatan yang tidak diperlukan dalam perdagangan internasional, dan pertimbangan terhadap kebutuhan negara berkembang untuk ekspansi pasar ke tingkat internasional.

Berdasar kajian pustaka dapat dikemukakan hipotesis yang akan diuji dalam penelitian ini yaitu: (1) ada perbedaan nilai ekspor negara-negara anggota ASEAN sebelum dan setelah Krismon 1998 serta (2) ada perbedaan nilai impor negara-negara anggota ASEAN sebelum dan setelah Krismon 1998.

\section{Metode Penelitian}

Menurut metodologinya, penelitian ini termasuk event study dan teknik pengumpulan data menggunakan dokumentasi. Dokumen yang dibutuhkan dalam penelitian ini yaitu nilai ekspor dan impor negara-negara anggota ASEAN yang dipublikasikan oleh The Asian Development Bank (ADB). 
Data penelitian terkait variabel penelitian yaitu ekspor dan impor. Nilai ekspor diukur dalam satuan unit uang, demikian halnya dengan nilai impor. Sedangkan skala pengukuran untuk nilai ekspor dan impor ini yaitu rasio. Sumber data penelitian ini yaitu data sekunder tentang nilai ekspor dan impor negara-negara anggota ASEAN yang dikumpulkan dari publikasi ADB yang bersifat annual. Data sebelum krisis selama 16 (enam belas) tahun, yaitu tahun 1982 sampai dengan 1997. Sedangkan data setelah krisis ekonomi tahun 1998 selama 16 (enam belas) tahun, yaitu tahun 1999 sampai dengan 2014.

Berdasar model rumusan masalah, penelitian ini termasuk dalam penelitian komparatif serta berdasar metode analisis data, penelitian ini diselesaikan menggunakan metode statistik inferensial khususnya statistik parametrik, menguji perbedaan rata-rata dua sampel berpasangan (Paired Sample t-Test), yaitu ekspor dan impor negara-negara anggota ASEAN sebelum dan setelah krisis ekonomi tahun 1998.

\section{Analisis}

\section{Data Eksisting Neraca Perdagangan Indonesia}

Neraca perdagangan Indonesia (yang ditunjukkan oleh kondisi dimana nilai ekspor lebih besar dari nilai impor atau surplus) dalam kurun waktu sebelum dan setelah Krismon 1998 menunjukkan trend yang meningkat secara signifikan. Booming peningkatan ini berjalan sampai dengan tahun 2006/2007, karena pada tahun 2008 terjadi krisis finansial global yang sepertinya juga berdampak terhadap perdagangan luar negeri Indonesia.

Disamping itu, perkembangan neraca perdagangan Indonesia (yang diproxy oleh nilai surplus) sangat dinamis dalam kuruan waktu penelitian baik sebelum maupun setelah Krismon 1998. Dinamika ini dipengaruhi oleh nilai tukar rupiah terhadap dollar Amerika Serikat, dimana sebelum Krismon 1998 nilai tukar rupiah terhadap dollar kurang dari Rp. 5.000,- dan seteleh Krismon 1998 nilai tukar rupiah lebih dari Rp. 10.000, sehigga berpengaruh terhadap peningkatan nilai surplus perdagangan Indonesia. 
Setelah krisis finansial global 2008 neraca perdagangan regional Indonesia mengalami perbaikan mengingat nilai surplus meningkat selama tiga tahun berturut-turut yaitu 2009, 2010 dan 2011, namun demikian mengalami penurunan bahkan defisid pada tiga tahun berturut-turut yaitu periode tahun $2012-2014$. Pada periode ini nilai impor Indonesia lebih kecil dibandingkan dengan nilai ekspor atau kegiatan menjual produk ke luar negeri lebih kecil dibandingkan dengan kegiatan membeli produk dari luar negeri.

\section{Data Eksisting Neraca Perdagangan Malaysia}

Perekonomian Malaysia yang ditunjukkan oleh perdagangan luar negeri dalam kurun waktu sebelum Krismon 1998 menunjukkan dinamika yang sangat tajam, dimana sebelum tahun 1990 neraca perdagangan Malaysia tumbuh tipis dan setelah tahun 1990 mengalami penurunan bahkan defisit. Namun demikian Krismon 1998 tidak membuat kondisi neraca perdagangan mengalami penurunan, karena pada periode ini justru mengalami peningkatan. Bahkan krisis finansial global 2008 nilai surplus perdagangan luar negeri Malaysia sedang booming walaupun hanya dalam jangka pendek, dimana setelah tahun 2008 mengalami penurunan walaupun tidak mengalami deficit.

\section{Data Eksisting Neraca Perdagangan Philipina}

Perekonomian Philipina dalam bentuk perdagangan internasional baik sebelum maupun setelah Krismon 1998 menunjukkan kinerja yang tidak baik. Hal ini ditandai dengan nilai ekspor yang lebih kecil dibandingkan impor sehingga berdampak pada neraca perdagangan yang negatif atau defisit (gambar 5). Tingginya impor ini berdampak pada menurunnya cadangan devisa nasional mengingat perdagangan internasional dalam bentuk impor memerlukan devisa, dan jika dalam jangka panjang maka akan berdampak pada buruknya kinerja perekonomian suatu negara termasuk Philipina. 


\section{Data Eksisting Neraca Perdagangan Singapura}

Krismon 1998 berdampak pada melemahnya perekonomi suatu negara, termasuk Singapura. Sebagaimana pada gambar 6 bahwa neraca perdagangan Singapura berada di wilayah kuadran negatifyang berarti defisit karena ekapor lebih rendah dibandingkan impor. Kondisi ini terjadi pada periode sebelum Krismon 1998, namun demikian perekonomian Singapura bangkit dan neraca perdagangan membaik yang ditunjukkan oleh nilai ekspor yang lebih tingggi dibandingkan impor sehingga perdagangan luar negeri dalam posisi surplus. Kondisi ini berlangsung lama yaitu selama sembilan tahun (1999 - 2007), dan pada tahun 2008 kembali mengalami penurunan atau neraca perdagangan dalam posisi defisit. Tahun 2008 dimana dunia mengalami krisis finansial global juga mempengaruhi perekonomian Singapura sebagai negara yang perekonomiannya kuat di kawasan ASEAN.

\section{Data Eksisting Neraca Perdagangan Thailand}

Perekonomian negara yang dikenal dengan sebutan "Gajah Putih" sungguh mengalami kemerosotan khususnya pada periode sebelum Krismon 1998, yang ditandai dengan neraca perdagangan luar negeri yang negatif atau defisit. Namun demikian kondisi ini berangsur membaik pada periode tahun setelah Krismon 1998 walaupun tidak begitu signifikan nilai surplusnya.

\section{Data Eksisting Neraca Perdagangan Vietnam}

Neraca perdagangan Vietnam lebih buruk dibandingkan Thailand dalam hal pencapaian surplus neraca perdagangan regionalnya. Pada periode sebelum dan akhir setelah Krismon 1998, neraca perdagangan Vietnam pada posisi negatif atau defisit. Neraca perdagangan mengalami peningkatan pada akhir periode penelitian yaitu pada tahun 2012, yang berati bahwa surplus neraca perdagangan Vietnam baru bisa terwujud pada tahun tersebut. 


\section{Uji Normalitas Data}

Hasil pengujian menunjukkan bahwa nilai Sig. atau signifikansi atau nilai probabilitas ekspor sebelum dan setelah serta impor sebelum dan setelah Krismon 1998 menunjukkan nilai lebih besar dari $\alpha=0,05$ (hasil uji normalitas pada masingmasing sampel penelitian disajikan pada tabel 1). Hasil ini berarti bahwa data berdistribusi normal sehingga data layak untuk diuji menggunakan statistika parametrik.

\section{Uji Beda Rata-rata Dua Sampel Berpasangan (Paired Sample t-Test)}

Berdasar Uji Paired Sample t-Test dapat dikemukakan bahwa terdapat perbedaan yang signifikan ekspor negara-negara anggota ASEAN sebelum dan setelah Krismon 1998, dimana relevan dengan penelitian Nugrahani dan Tarioko (2011) bahwa ekspor sebelum dan sesudah krisis berbeda walaupun sampel penelitian dan periodisasi penelitian berbeda. Penelitian ini juga mendukung studi Ragimun (2016), bahwa rata-rata ekspor sesudah ACFTA juga mengalami kenaikan dibanding sebelumnya. Hasil penelitian ini juga relevan dengan penelitian Maramis (2013) bahwa terdapat perbedaan ekspor neto Sulawesi Utara sebelum dan sesudah krisis finansial global 2008 dan terdapat perbedaan ekspor neto Indonesia sebelum dan sesudah krisis finansial global 2008.

Dalam kaitannya dengan impor, hasil penelitian ini relevan dengan studi Gultom, et al (2013) bahwa terdapat perbedaan nyata antara volume impor jeruk, harga jeruk impor, volume ekspor jeruk, harga jeruk domestik sebelum dan sesudah CAFTA (China ASEAN Free Trade Area). Tidak terdapat perbedaan nyata harga jeruk ekspor sebelum dan sesudah CAFTA (China ASEAN Free Trade Area). Volume impor jeruk sesudah CAFTA lebih tinggi dibandingkan sebelum CAFTA. Volume ekspor jeruk sesudah CAFTA lebih rendah dibandingkan dengan sebelum CAFTA. Harga jeruk impor, harga jeruk ekspor, harga jeruk domestik Sumatera Utara lebih mahal sesudah CAFTA dibandingkan dengan sesudah CAFTA. 
Studi ini juga mendukung penelitian Kartika (2008) yang menyebutkan bahwa pada bulan Februari 2009 pemerintah mendorong masyarakat Amerika Serikat untuk membeli produk domestik serta penggunaan bahan baku lokal dalam setiap pembelanjaan proyek pemerintah. Selain itu pemerintah Amerika Serikat juga memberlakukan restriksi terhadap berbagai produk impor dari berbagai negara, baik dengan hambatan tarif maupun non tarif serta bersifat teknis maupun non teknis. Berbagai kebijakan yang dikeluarkan oleh pemerintah Amerika Serikat tersebut dinilai bersifat proteksionis dan tidak konsisten dengan prinsip WTO yang mengedepankan tiga hal yaitu anti diskriminasi produk, mengurangi atau menghilangkan batasan dan hambatan yang tidak diperlukan dalam perdagangan internasional, dan pertimbangan terhadap kebutuhan negara berkembang untuk ekspansi pasar ke tingkat internasional.

\section{Kesimpulan}

Berdasar analisis data dapat dikemukakan bahwa perdagangan internasional dalam bentuk ekspor pada negara-negara anggota ASEAN berbeda sebelum dan setelah Krismon 1998. Demikian halnya dengan impor, yaitu terdapat perbedaan sebelum dan setelah Krismon 1998. Hasil ini mengisyaratkan bahwa Krismon 1998 mempengaruhi nilai ekspor dan impor regional ASEAN. Berdasar nilai selisih ekspor dan impor, neraca perdagangan Indonesia menunjukkan nilai yang surplus terutama setelah Krismon 1998. Nilai suplus ini disebabkan antara lain oleh tingkat exchange rate mata uang rupiah dibandingkan dengan dollar Amerika Serikat. Sedangkan vietnam merupakan negara yang paling rendah prestasi ekonominya jika ditinjau dari aspek perdagangan luar negeri, karena posisi neraca perdagangannya defisit. 


\section{Daftar Pustaka}

Al-Hartsi, Jaribah bin Ahmad. 2006. Fikih Ekonomi Umar bin AlKhathab. Jakarta: Pustaka Al-Kautsar Grup.

Benny, Jimmy. "Ekspor dan Impor Pengaruhnya Terhadap Posisi Cadangan Devisa di Indonesia". Jurnal Emba. Vol.1, No.4. Desember. 2013.

Fuad, A. Jauhar dan Agus Eko Sujianto. 2014. Analisa Statistik dengan Program SPSS. Tulungagung: Penerbit Cahaya Abadi.

Herdiansyah, Haris. 2012. Metodologi Penelitian Kualitatif untuk Ilmu-ilmu Sosial. Jakarta: Salemba Humanika.

Huda, Nurul; Handi Risza Idris; Mustafa Edwin Nasution; Ranti Wiliasih. 2008. Ekonomi Makro Islam Pendekatan Teoretis. Jakarta: Kencana Prenada Media Group.

Kartika, Maya Meralda. Proteksionisme amerika serikat pasca krisis finansial 2008". Jurnal Analisis Hubungan Internasional. Vol. 3, No. 2. 2013.

Kurniawan, Bayu. Perbedaan Profitabilitas Bank Syariah Sebelum dan Sesudah Adanya Fatwa MUI tentang Bunga Bank Jurnal Iqtishoduna. Vol.6, No.2 Tahun 2010.

Mankiw, N. Gregory. 2006. Pengantar Ekonomi Makro. Jakarta: Salemba Empat.

Mannan, Muhammad Abdul. 1997. Teori dan Praktek Ekonomi Islam (Dasar-dasar Ekonomi Islam). Yogyakarta: PT Dhana Bhakti Prima Yasa.

Maramis, Christie N. J. Analisis Pertumbuhan Ekonomi, Konsumsi, Investasi, dan Ekspor Neto di Indonesia dan Sulawesi Utara Sebelum dan Sesudah Krisis Finansial Global Tahun 2008. Jurnal EMBA. Vol.1, No.4. 2013.

Gultom, Maria, Tavi Supriana, Salmiah. Analisis Dampak CAFTA (China Asean Free Trade Area) Terhadap Perdagangan Jeruk Sumatera Utara. Journal on Social Economic of Agriculture and Agribusiness. Vol. 2, No. 5. 2013.

Nugrahani, TriSiwi dan Dian Hiftiani Tarioko. Perbedaan Pertumbuhan Ekonomi, Investasi Domestik Dan Ekspor Antara Sebelum dan Sesudah Krisis AKMENIKA UPY. Vol. 8, No. 2. 2011. 
Nugroho, Bhuono Agung. 2005. Strategi Jitu Memilih Metode Statistik Penelitian dengan SPSS. Yogyakarta: Penerbit ANDI. O'Sullivan, Arthur and Steven M. Sheffrin. 2003. Economics: Principles in Action. Upper Saddle River. New Jersey: Pearson Prentice Hall.

Ragimun. Analisis Investasi China ke Indonesia Sebelum dan Sesudah ACFTA, http://www.kemenkeu.go.id/sites/default/ files/Analisis\%20investasi\%20China\%20ke\%20Indonesia\%20 sebelum\%20dan\%20sesudah\%20ACFTA.pdf, diakses tanggal 24 April 2016.

Riduwan. 2012. Dasar-dasar Statistika. Bandung: ALFABETA.

Sabaruddin, Sulthon Sjahril. Dampak Perdagangan Internasional Indonesia terhadap Kesejahteraan Masyarakat: Aplikasi Structural Path. Buletin Ekonomi Moneter dan Perbankan. Vol. 17, No 4. April 2015.

Safitriani, Suci. Perdagangan Internasional dan Foreign Direct Investment di Indonesia Buletin Ilmiah Litbang Perdagangan. Jakarta: Kementerian Perdagangan RI, Vol.8 No. 1, Juli 2014. Salamah, Lilik. Lingkaran Krisis Ekonomi Indonesia. Masyarakat, Kebudayaan dan Politik. Th XIV, No 2, April 2001, 65-76, http://journal.unair.ac.id/filerPDF/06-lilik.pdf, akses 20 April 2016.

Samuelson, Paul A. and William D. Nordhaus. 1995. Economics. Fifteenth Edition, McGraw-Hil.

Septididya, Mohammad. Pelaksanaan Perjanjian Jual Beli dengan Menggunakan L/C (Letter Of Credit) Pada PT Batik Danar Hadi Surakarta. Naskah Publikasi. Fakultas Hukum Universitas Muhammadiyah Surakarta 2013.

Setyowati, Endang; Rianasari Damayanti; Subagyo; Rudy Badrudin; Suryawati K.; Algifari; Haryono Subiyakto; Sri Fatmawati; Astuti Purnamawati. 2004. Ekonomi Makro Pengantar. Yogyakarta: Sekolah Tinggi Ilmu Ekonomi Yayasan Keluarga Pahlawan Negara Yogyakarta.

Sloman, John dan Keith Norris. 2005. Principles of Economics. Australia: Pearson Education. 
Sujianto, Agus Eko. 2009. Aplikasi Statistik dengan SPSS 16.00. Tulungagung: Penerbit Cahaya Abadi.

Sujianto, Agus Eko. 2016. Bab 9: Neraca Pembayaran \& NilaiTukar. Materi Kuliah Pengantar Ekonomi Makro. Tulungagung: FEBI IAIN Tulungagung.

Sukirno, Sadono. 1998. Pengantar Teori Makroekonomi. Edisi Kedua, Jakarta: PT RajaGrafindo Persada.

Sukirno, Sadono. 1996. Pengantar Teori Mikroekonomi. Jakarta: PT RajaGrafindo Persada.

Suwignyo, Dwi. 2010. Kompilasi Tafsir Ayat-ayat Ekonomi Islam. Yogyakarta: Pustaka Pelajar.

Wahyuni, Sri dan Indarwati. "Analisis Pengaruh Ekspor-Impor China Terhadap Laju Pertumbuhan Ekspor dan Impor Indonesia Menjelang ACFTA di Implementasikan". Jurnal Variasi. Fakultas Ekonomi Universitas Al Muslim Bireuen. Vol 2, No 4. 2010. 